\title{
Kidney Stone Disease of Non Gouty Origin in 264 Popes (34-2005 AD): A Historical Review
}

\author{
Natale Gapare De Santo ${ }^{1 *}$, Carmela Bisaccia ${ }^{2}$ and Luca Salvatore De Santo ${ }^{3}$ \\ ${ }^{1}$ University of Campania Luigi Vanvitelli Naples, Italy \\ ${ }^{2}$ Mazzini Institute Naples, Italy \\ ${ }^{3}$ Department of Medical Translational Division, Division of Thoracic Surgery, University of Campania Luigi Vanvitelli, \\ Italy
}

\begin{abstract}
A total of 11 non-gouty popes out of 264 (4.1\%) died of kidney stones (very probably calcium stones) between the years 34-2005 AD. The prevalence of kidney stones was lower than expected on the basis of recent population-based data. The discrepancy might be due to the changing nutritional habits. Causes of death included acute kidney injury, chronic kidney disease, and stroke.

The disease was highly recurrent in 9 of 11 (88.1\%). Recurrences were observed 1 to 30 years after the first attack. Mean age at death was 63.1 years, much shorter than expected in popes. Clinically recurrent back-flank-groin pain emerged as a hallmark indicator of kidney stones in the narratives. It was sometimes associated with fever, hematuria, purulent urine and/or frequent urination and dysuria. Some popes were obese, sedentary, voracious and wine drinkers; others were lean, took long walks, ate frugal meals and practiced restraint when it came to drinking alcohol. They were cured with bed rest, diets, donkey milk, mineral waters, decongestant, purgatives, thermal baths, blood-letting, and surgery.
\end{abstract}

Keywords: Popes; Urinary calcium stones; CKD, Acute kidney injury; Urosepsis; Stroke; Renal deaths

\section{Introduction}

\section{OPEN ACCESS}

${ }^{*}$ Correspondence:

Natale Gaspare De Santo, University of Campania Luigi Vanvitelli Naples, Italy, E-mail: NataleGaspare.Desanto@ unicampania.it

Received Date: 22 Jul 2021

Accepted Date: 20 Sep 2021

Published Date: 23 Sep 2021

Citation:

De Santo NG, Bisaccia C, De Santo

LS. Kidney Stone Disease of Non Gouty Origin in 264 Popes (34-2005 $A D)$ : A Historical Review. Clin Surg. 2021; 6: 3307.

Copyright $\odot 2021$ Natale Gapare De Santo. This is an open access article distributed under the Creative Commons Attribution License, which permits unrestricted use, distribution,

and reproduction in any medium, provided the original work is properly

cited.
Kidney Stone Disease (KSD) is a complex clinical condition with a prevalence of $8 \%$ to $10 \%$ in population-based studies and a $30 \%$ to $50 \%$ recurrence at 5 years (i). Up to $70 \%$ to $85 \%$ of kidney stones are made of calcium (approximately $60 \%$ to $70 \%$ as calcium oxalate, $15 \%$ as calcium phosphate). Stones formed from uric acid account for $5 \%$ to $10 \%$ of all renal stones.

The disease matters to patients because of excruciating flank pain, statesmen because of costs and scientists looking for new unifying knowledge, theories, cures and guidelines for a disease that is strongly linked to aging and lifestyles [1] and has accompanied humankind since its beginning.

Recent studies indicate that KSD is driven by polygenic inheritance strictly intertwined with nutritional habits [1-3]. A brilliant future for research in the field and many good results can be expected from studies in KSD that in turn is associated with chronic kidney disease, myocardial infarction, stroke and metabolic syndrome through insulin resistance [4-9].

Recent studies have shown that popes represent an interesting model to study kidney stone disease [10-15]. They are people of affluence and distinction belonging to the upper socioeconomic class with the advantage of being highly educated and benefiting from having their health monitored by in numerous archiaters and personal physicians. The mean life span of 51 popes who ruled in the years 1492-2005 was 73.4 years [16]. In addition, the lives of popes from the year $1000 \mathrm{AD}$ onwards have been scrutinized thoroughly since popes have been key players in the history of Europe and beyond. Thus, their lives attracted not only their physicians, but also historians. The number of records on the health of popes is enormous and everyday new documents are discovered throughout Europe.

Our studies have also investigated kidney stone disease of gouty origin in 264 popes from Saint Peter to Saint John Paul II (34-2005)) and have showed that 25 (9.5\%) of them were affected [10-16]. To understand the global burden of Kidney Stone Disease among popes also calcium nephrolithiasis should be explored since a few non-specific study exist $[17,18]$. 
The present study aims to characterize KSD of non-gouty origin among the 264 popes reigning in the years 34-2005 AD. The study never attempted before may shed light on the natural history of Kidney Stone Disease in popes. Data will be shown indicating that a total of 11 popes living between the years 34-2005 AD) were calcium stone formers $(4.1 \%)$.

\section{Methods}

\section{Expected number of popes suffering of kidney stone disease}

Taking into account $10 \%$ as the upper limit of prevalence of kidney stone disease in population-based data [1] we might expect that among 264 popes (from St. peter to St John Paul II, a total of 26 popes suffering from nephrolithiasis, $70 \%$ to $85 \%$ were calcium stones formers (a maximum 22), 10\% uric acid stone formers (a maximum of 3 ) and $5 \%$ were affected by other stones (one pope). Summing up, we might expect that 26 popes with kidney stone disease, 22 had calcium stones, 3 had uric acid stones and 1 had some other stones.

\section{Literature search}

We have compiled the clinical narratives of all popes with kidney stone disease of non-gouty origin by scrutinizing (i) the histories of popes and archiaters $[19,20]$ of Bartolomeo Sacchi known as Platina (1421-1481), Luigi Gaetano Marini (1782-1815); (ii) the histories of papacy [21-24] of Giuseppe de Novaes (1736-1821) Leopold von Ranke (1795-1896), Mathieu-Richard Auguste Henrion (1805-1862), Ludwig von Pastor (1854-1928); (iii) recent monographs on popes and papacy [25,26] of Agostino Paravicini Bagliani, and of Peter G. Maxwell-Stewart, and Wendy J. Readon [27,28] and (iiii) the encyclopedias on line Britannica, Catholic and Treccani [29-31] and Breve Storia dei Papi of C. Castiglioni [32].

\section{Elements to build clinical narratives}

Research was centered on the first renal colic, the age of the pope and recurrences and age at death. Notes were taken about localization, intensity and radiation of pain, its association with restlessness, nausea, vomiting, urinary urgency, passing of blood, clots, sands, stones or fragments of stones, dysuria, pyuria, fever, duration of single episodes, the cure prescribed by archiaters and personal physicians, and those arousing from the additional consultation with famous physicians, cause of death, renal deaths, cardiovascular disease, stroke, and inability to perform papal duties. Signs of acute kidney injury (urine suppression, fluid retention, urosepsis), chronic kidney disease (nocturia, uremic skin pallor), autopsy findings (stones, renal pathology) were also recorded. The narratives of the 11 popes will be accompanying the manuscript as supplementary material.

\section{Narratives}

\section{Vigilius b. around 500-505, pope 3/27, 537-6/7, 555}

Born to a Noble family in Rome. His father was consul, his brother senator. He had to be nominated pope at the time of the Election of Pope Agapitus I. Later he was apostolic nuncio in Constantinople and became Pope after the abdication of Pope Silverius. He died in Syracuse on a trip back to Rome from Constantinople. De Novaes

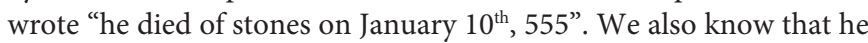
could not attend a Council convened by Emperor Justinian on 5 May 533 because of "mal della pietra/renal stone disease [33]. "He died because of the pain caused by stones" [34]. He was the first pope who suffered from kidney stones of non gouty origin.

\section{Gregory IX b. c.1170 pope 3/19, 1227-8/22, 1241}

Born Ugo of Anagni of Conti of Segni, a cousin or nephew of
Honory III. He studied law in Bologna and Paris, became deacon in 1196, cardinal Bishop of Anagni and Velletri in 1206, and papal delegate to Tuscany, Germany, and Lumbardy. He was a personal friend Robert Grosseteste (chancellor of Oxford), of Domenico Guzman and Francis of Assisi. He helped the latter in receiving the approval of his Regula. De Novae's says that he was nominated pope one day after the death of Honory III. He was a strong man, a scholarly, skillful and subtle jurist. He enrolled Raymond of Peñafort (his former professor at the University of Bologna) to give unity to papal laws. A great cultural enterprise that had roots in Justinian. This was the birth of Decretales and Constitutiones that were transferred to the universities of the Catholic Church including Paris in order to be used in teaching. Gregory was a powerful pope. He excommunicated Emperor Frederic II twice, but signed the peace of San Germano with him on July $23^{\text {rd }}, 1230$.

He died at an elderly age with bladder stones [35]. Matteo Paris a chronicler of his time wrote "fuit calculosus et caruit balnesi, quibus solebat Viterbii confoveri", which means he was cured in the thermal baths of Viterbo.

\section{Gregory XI b. 1329, pope12/30, 1370-3/27, 1378)}

Born Pierre Roger de Beaufort in Avignon, bearing the same name as his uncle Clement VII who nominated him cardinal deacon at the age of eighteen. Gregory studied at the University of Perugia where he became expert canonist and fine theologian. He was elected pope at age thirty-nine and crowned Pope on January $4^{\text {th }}, 1371$ after being ordained. He is the pontiff who decided to move the papacy back from Avignon to Rome. He departed on horseback from France in September and arrived in Rome in June 1377.

He died in Rome in 1378 on $28^{\text {th }}$ March at age forty-seven "because of stone pains that tormented him and also because he was sickly and of weak constitution" $[35,36]$. "Ex morbo petrae et intolerabili dolore vesicae/of kidney stones and of intolerable bladder pain" [37].

\section{Boniface IX b. c1356, Pope 11/3, 1389-11/2/1404}

In c.1356 (Britannica) Pietro Tomacelli was born at Casarano (Apulia), in the Kingdom of Naples. His early studies were with Benedictines at the local Monastery, then at the Studium of Naples. In 1384 he was nominated Cardinal Deacon by Urban VI. He reigned at the time of the Western Schism (1378-1417). Boniface Celebrated two jubilee years $(1389,1400)$. It was a time when the church needed to fill its coffers when Rome had less appeal than Avignon and had limited economical resources. He entered the universities of Ferrara (1391) and Fermo (1398) and confirmed that of Erfurt (1392). He has been described as a "nepotistic bureaucrat centralizer, a prince more than a spiritual shepherd" says Cosmacini. He enrolled a huge number of archiaters and a favorite attending physician, the Jewish Angelo di Emanuele "artium et medicinae doctor"/doctor in arts and medicine.

"Boniface endured, as he had many times before, bouts of renal stones and high acute fever that lasted three days and caused his death on October $1^{\text {st }}, 1404$ after having governed the church for fourteen years and eleven months" [20].

Because of his disease his archiater Angelo Domenichelli della Torre suggested he have a sexual intercourse to move the stones "per coitum cum muliere liberaretur a calculo, ex quo decessit" he decided that "It is better to die chastely than to live shamelessly" [20]. Wendy J Reardon says "He died of kidney stones at age 54" [21]. 


\section{Hadrian VI, b. 3/2, 1459, pope 1/9, 1522-9/14, 1523}

Born in Utrecht, Adriaan Florenszoon Boeyens d'Edel, he was not present at the conclave (a possibility forbidden thereafter) that elected him pope and never changed his name after election. He is famed for leading a life of sanctity for lifestyle, studied theology and philosophy at the University of Louvain where he later was elected vice chancellor. He had been preceptor of Charles $\mathrm{V}$, the future emperor who was seven years old, and for this reason had ties to the Government of Spain during the mentoring of Charles V. He had been General Inquisitor of Tarragona in 1516 and cardinal since 1517. He ate sparingly, and lived without luxuries and when in Rome he had just 2 servants. Hadrian VI was the last non-Italian pope before John Paul II.

"Hadrian VI died of renal stone that caused him intolerable pains for more than thirty days". "On August $19^{\text {th }}$ he had flank pain due to gravels" [39-41]. He had high fever and complained of weakness that made him unable to celebrate mass. At death he was sixty-four years old. The final illness started with a postauricular abscess.

\section{St. Pius V (b. 1/17, 1504, pope 1/7, 1566-5/17, 1572}

Born into a poor family, Michele Ghisleri in Bosco Marengo (Alessandia), a poor family he earned a living in his early life as a shepherd. As a Dominican novice, he became Friar Michel, inquisitor bishop and great inquisitor in 1551 and cardinal in 1552. Pius V was a strong pope who applied the resolution of the council of Trent. He favored crusades, reformed the church, killed many heretics, was supported by Paul IV for introducing the Index of Prohibited Books, and created a special congregation for that in 1571. Under his reign it was prohibited for wet-nurses to breast-feed Jewish children on the day they received sacramental bread (Bulla Super gregem Dominicum), secluded Roman prostitutes in a special quarter surrounded by walls and guarded its entrance, in Rome at Castel sant'Angelo. He confined the Jews to a ghetto, limited the liberty of Jewish physicians, obliged physicians to stop cures to patients if they did not confess within three days, and imposed confession before admission to hospices as well as to hospitals.

He enlarged the Botanical Garden of Rome, nominated master of Chapel Giovanni da Palestrina and had a great relationship with Vasari for the Adorazione dei Magi of the Convent of Holy Cross and All Saints in his native town.

A man of strong will an avid walker (8 miles a day), he ate sparingly and was a sober wine drinker, but he was a frequent faster and was excessively thin (this lead Giorgio Cosmacini to suspect a gastrointestinal problem). His medical history was characterized by pain due to mal della pietra (kidney stones) for 18 years, with bouts of hematuria, sometimes pyuria, acute fevers, flank pain, dysuria, emission of sands and small stones and by the autopsy findings of 3 blackish stones, each 1 inch in size, occupying the pelvis bilaterally. For this he drank donkey milk, a therapy dating back to Rufus of Ephesus (I-II Century) and supported also by Girolamo Mercuriale (1530-1606). The first episode was recorded in 1555, lasted 20 days, and was ascribed to his journey on mule back. The second episode dated to 1557 and characterized by milky urine, polyuria, burning, with genital pain, emission of sands and of stones the size of chickpeas treated with white grape must. On that occasion he partook of the famous waters of Bagni di Lucca. A place that catered to famous patients including Pope Pius IV, Giuliano de' Medici, Alfonso of Ferrara, Gabriel Falloppia (the anatomist), Michel de Montaigne and at later time James II, Louis Bonaparte, Josephine Beauharnais. Other bouts of renal stone disease occurred in 1564, 1566. The last bout of nephrolithiasis occurred at the beginning of 1572. It lasted for 40 days and was marked by continuous excruciating pain. He refused surgery since he did not allow any physician to see or touch him. He just drank donkey milk that his stomach no longer tolerated. This long episode of flank pain, high fever, vascular disease, arrhythmia with heart blockage, syncope, aphasia, probably stroke, ended in his death [41].

\section{Gregory XIV b. 2/11, 1535, pope 12/5, 1590-10/8, 1591}

Niccolò Sfondrati was delivered in the seventh month of pregnancy by Cesarean section, at the family castle, which still stands in Somma Lombardo near Milan. His mother belonged to the Visconti family. His father was senator at the Court of Carlo Sforza in Milan.

Niccolò inherited the title of Count of the Sacred Roman Empire and the vast properties of his father. In 1551 he was ordained priest, became abbot of Civitale and senator of the City of Milan. He studied in Milan and attended the University of Padua where he graduated "in utroque jure"/civil and canonical law. In 1560 Gregory XIV was nominated bishop of Cremona, he participated at the Council of Trent in 1561-1563, was nominated Cardinal in 1563, and elected pope in 1590. He loved music and supported the Papal Musical Chapel. Giovanni Pierluigi Palestrina dedicated the Magnificat octo tonum to him. A Pious man-his days started by reciting the 7 psalms kneeling down and reading the Bible-he ate sparingly and drank very little wine. Gregory fasted every Friday and avoiding meat on Wednesdays.

But he was sickly, suffered from renal stone disease that was ascribed to the fact that he drank only water. His disease started during his travel to Rome for the Conclave that elected him pope. $\mathrm{He}$ had to stop in Modena because of bladder stones. He was treated by Simone Castelvetro who later became his archiater and with his three assistants was housed in the Vatican with a high salary and benefits.

"His infirmity was characterized by dysuria" [42]. "He had bladder disease since April, thus he decided to move to his summer house on Mount Quirinal. The disease recurred on $5^{\text {th }}$ July." "In September Gregory suffered again because of his lithiasis. High continuous fever supervened and he asked for last rights (The holy viaticum). His pains ended in the night of October 15-16, 1591" [43]. An autopsy revealed a big stone (the size of an egg) in the bladder weighing two ounces the kidney and the lung were full of blood as reported by Marini [44].

\section{Leo XI b. 6/2, 1535, pope 4/1, 1605-4/27, 1605}

Born in Florence, Alexander Ottaiano de' Medici, belonged to a minor branch of the great family. He was the son of Ottaiano and Francesca Salviati and nephew of Leo X. In his twenties he became priest. Cosimo Medici nominated him personal ambassador to the pope. In this office he pleased both Cosimo and Popes Pius V and Clement XIII [45]. In 1573 he was nominated bishop of Pistoia, and in 1583 cardinal and chief of a very important mission to France. Twenty years later, French cardinals backed him in the conclave that elected him pope at 70 years of age. A pious man he suffered from renal stone disease. He died 27 days after election from an acute disease associated with fever, contracted when taking possession of the Lateran Church. Probably acute pyelonephritis. Autopsy revealed intact intestines, left lung inflammation, many small stones were found in the bladder along with a larger one -the size of a nut. 


\section{Alexander VII b. 2/13, 1599, pope 4/7, 1655-5/22, 1667}

Fabio Chigi was born to a wealthy noble family in Siena. His parents were Flavio Chigi Ardenghesca and Laura Marsili who had ten children. His father, a banquer, was the nephew of Pope Paul V. Fabio grew fragile and sickly. As a child he had a form of undefined apoplexy. His forehead was high, his eyes inquisitive, the black hair contrasted with his pale skin.

He obtained degrees in civil and canonic law, philosophy and theology. At a very young age he entered in the prelatura of Urban VIII who recognized his talents and utilized them in various offices: refendary of the Tribunal of Signature for Justice (1629), inquisitor of Malta (1632), bishop of Nardò (1635), Nuncio at Cologne (1639), Cardinal (1652), Archbishop of Imola (1652-1655).

He was elected pope in a Conclave lasting 80 days. Alexander VII was a man of exquisite taste, a patron who adorned Rome with monuments. He was a patron of scientists and artists and loved Gianlorenzo Bernini, so he inspired and protected him for the Colonnade of Saint Peter, and let him make maximal use of his talents in building the Scala Regia from the Basilica to the papal palace (a great change from the original Sangallo project). He backed the Jesuits against jansenists, was friend of literati scientists and artists. He donated the Alexandrina Library to the University of Rome in 1670.

Fabio Chigi was always sick. While apostolic nuncio at Cologne he had bladder stone disease. Following the advice of many intellectual friends he underwent a complex surgical procedure because of the size of the stone (struvite?) to be removed. "The operation was performed on 8 November 1642. The bladder was cut and attempts were made to remove the large and fragile stone that was splintered into pieces by means of tongs. The procedure was replicated twice on subsequent days. Since pain was intractable it was deemed wise to allow him to convalesce from the intensity of the pains that might have killed him. The total weight of the various fragments amounted to 10 ounces" "The bladder never recovered fully and Fabio needed to empty it frequently, more at night than during the day". Following the operation he needed "cures for 96 days, and he lost six pints of blood, continued to experience intractable pain and paid 2000 scudi [golden coins, each not less than three grams on those days. A huge medical fee typical for rank and the richness of the family]. His bladder was forever damaged and ne needed to empty it more at night than during the day" [46]. Upon the death of Innocent X he was elected pope at the end of Conclave lasting 80 days. Prematurely aged, he had lost his teeth during his service in Germany. He was a hard worker but took long periods of rest in spring and fall at Castel Gandolfo since he continually "suffered from bladder and kidney disease" that required the care and the cures of "the learned Mattia Naldi [47]. According to De Novaes in those years he suffered from "podagra, phlegm, stones with a bit of fever [48].

This is the only reference to podagra that led Lorenzo Gualino to include Alexander VII among gouty popes, whereas everything supports the notion of a non gouty stone disease.

His last five months were "a chain of heavy bodily pains". He was feverish "lost a considerable amount of weight", "he was like a skeleton (Pastor XIV p. 394). Since March he was forced to bed". "On 16 May his conditions deteriorated and on the evening of May $22^{\text {nd }}$ he died". "Autopsy did not reveal presence of stones; however the left kidney was full of purulent whitish material, not bad smelling. It contaminated the spleen and the upper lobe of a lung. In the bladder there were "three fatty glands". "Everything had started with fall from the horse at Castel Gandolfo". "However no stone was found, thus the diagnosis of stone disease was not confirmed "but physicians had been of a different opinion and mismanaged him [49].

\section{Clement IX, b. 1/28, 1600, pope 6/20, 1667-12/9, 1669}

Born in Pistoia to a noble family with roots from Lombardy, Giulio Rospigliosi studied in Rome guided by Jesuits and later at the University of Pisa where he obtained the degree in philosophy and theology. He became domestic prelate of Pope Urban VIII (1641). He was nominated nuncio to Spain (1644-1653). A renowned poet and author of melodramas he became state secretary and cardinal in 1655 then elected pope on June $30^{\text {th }}, 1667$ after a 15 days conclave. French cardinals favored his election.

Clement IX put a limit of 15 baiochi a day to be spent on food for his table (Baiocchi, a coin of Merovingian origin, connected with the city of Baiocas, adopted by the Vatican and by many other states).

He suffered from renal stone diseases since his election to cardinal. On the vesper of January $5^{\text {th }}, 1669$ he experienced a nonfatal stroke from which he fully recovered. On $25^{\text {th }}$ October he had a second episode and was back to work on the $1^{\text {st }}$ of November. Flank pain associated with continuous fever and abundant phlegm recurred and were constant for the whole month. He did not survive the third stroke on $2^{\text {nd }}$ December. He received the sacraments of-last rights and died on $9^{\text {th }}$ December. A notice of 14 December reads: "The pope who for last month and a half has experienced pains due to kidney stones and fever has died after a $30 \mathrm{~h}$ agony 3 hours before dawn" [50].

From the dispatches of Antonio Grimani one learns that during his last month Clement IX had difficulty breathing with abundant phlegm treated with vesicants and manna (expectorant, decongestant and laxative). On $16^{\text {th }}$ November he had flank pain due to renal stones. Pain was an intractable for the whole month and he was forced to bed. He was near death on many occasions and on $29^{\text {th }}$ November there was a resurgence of-colic that never ceased during the subsequent days. He died at midnight preceding $9^{\text {th }}$ December [31].

\section{Innocent XIII b. 5/13, 1655, pope 5/8, 1721-3/7, 1724}

Born Michelangelo Conti, as second son of Carlo Conti, Duke of di Poli, and of Isabella Muti in Rome. His early studies were in Ancona under the guidance of the bishop of that city (a relative of his family). Subsequent studies were at the Roman College and at the University of Rome where he earned a degree in Civil and canonic law. Michelangelo was chief of the Papal delegation honoring Morosini in Venice (1690), governor of Viterbo (1693), assistant to the Holy See (1696), nuncio to Switzerland (1697), nuncio to Portugal (1698), Cardinal 1706, Bishop of Viterbo 1712-1717), elected pope in a Conclave lasting 40 days.

This obese, sedentary pope had three giant abdominal wall hernias through which intestines protruded frequently despite use of a truss. This was a hidden disease protected life-long by his servant who helped him to reduce the bulge. He also suffered from renal stones and "a bit of fever" alternating with foot edema, common cold, gastrointestinal disturbances, and the pains caused by stone sometimes associated with emission of purulent material. He drank water from Vetriolo (a spring near Trent), underwent purgation, bloodletting, applications of leeches and cautery on the thighs. All attempt led to naught as did the daily consultations with his physicians. The pope adhere the medical prescriptions, being unable to refuse. He was not able even to talk to 
Table 1: Popes with renal stone disease (non-gouty origin).

\begin{tabular}{|r|l|l|c|c|}
\hline \multirow{2}{*}{ No } & \multirow{2}{*}{ Name } & \multirow{2}{*}{ Place of Birth } & \multicolumn{2}{c|}{ Time of the Pontificate } \\
\cline { 4 - 5 } & & & Start & End \\
\hline 1 & Vigilius & Rome & $3 / 27,537$ & $6 / 7,555$ \\
\hline 2 & Gregory IX & Anagni & $3 / 19,1227$ & $8 / 22,1241$ \\
\hline 3 & Gregory XI & Rosiers d'Egleton & $12 / 230,1370$ & $3 / 27,1378$ \\
\hline 4 & Boniface IX & Casarano & $11 / 3,1389$ & $11 / 2,1404$ \\
\hline 5 & Hadrian VI & Utrecht & $1 / 9,1522$ & $9 / 14,1523$ \\
\hline 6 & Pius V & Marengo & $1 / 7,1566$ & $5 / 17,1572$ \\
\hline 7 & Gregory XIV & Somma & $12 / 5,1590$ & $10 / 8,1591$ \\
\hline 8 & Leo XI & Florence & $4 / 1,1605$ & $4 / 27,1605$ \\
\hline 9 & Alexander VII & Siena & $4 / 7,1655$ & $5 / 22,1667$ \\
\hline 10 & Clement IX & Pistoia & $6 / 20,1667$ & $12 / 9,1669$ \\
\hline 11 & Innocent XIII & Poli & $5 / 8,1721$ & $3 / 7,1724$ \\
\hline
\end{tabular}

his collaborators, everything was postponed. Innocent's conditions did not ameliorate over time. He became the subject of experimental attempts without relief. His legs were swollen, he became dyspneic, and dropsy became irreversible. He probably died following the latest intestinal herniation that was followed by high fever and dropsy. Probably herniation caused a drop in blood pressure and septic shock followed by acute kidney injury.

"He was hydropic and feverish. Epsom salts used to reduce edema caused convulsions (toxicity of sulphate from coexisting anuria?), swelling of the abdomen, erysipelas, suppuration, gangrene and fever. He died of disease and medical science" [51].

Von Pastor is precise about the Calvary of his last days: "On $12^{\text {th }}$ February the pope was ill. There was hope that the stone disease might be transient. However he deteriorated, the colic recurred daily and worries rose about life. He was weak. On $29^{\text {th }}$ February he was hydropic. There was alternation of good and bad days. However hydropsy was stable. He died on March $7^{\text {th }}$. To judge him a pope of transition one shall take into consideration his status of permanent infirmity and the brevity of the pontificate" [51]. It should be stressed that there were no days without disease.

\section{Results}

A total of 11 non gouty popes out of 264 (4.1\%) died from calcium stone disease between the years 34-2005 (Table 1 \& Figures 1-3). Hadrian VI was German and Clement IX was French, the remaining were Italians. The disease was recurrent in 9 of 11 popes.

Hadrian VI was robust, ascetic, consumed little meat, sometimes drank soup and ate fish on lean days. Pius IV was a frugal eater, sober wine drinker, and an avid walker (up to 8 miles a day). Leo XI was a great consumer of wine (Greek wine, Malvasia and/or robust French wine). Clement IX drank just plain water. Innocent XIII was sedentary and affected by progressive obesity.

Clinically recurrent back-flank-groin pain emerges as a marker of calcium stone disease in the above narratives. Sometimes it was associated with fever, hematuria, purulent urine and frequent urination and dysuria. Gregory XIV had pain and bouts of hematuria after carriage rides and physical exertion. KSD was of short duration (three weeks) and presented with fever and identified as a contributing cause of death) in Leo XI. It was of short duration in Gregory XI, and lasted less than two years in Gregory IX. It lasted two years 2 episodes, the second mortal-in Vigilius, fifteen years in Clement IX, eighteen years in Pius V, twenty-six years in Alexander VII, thirty years in Hadrian VI. KSD was of long duration in Gregory IX and Boniface IX who suffered from various bouts of KDS with fever). Recurrent feverish stone disease with hematuria and purulent urine contributed to the demise of Innocent XIII, who suffered from recurrent intestinal herniation from 3 giant abdominal wall hernias that he never disclosed to his personal physicians and archiaters. The last attempt to reduce protrusion of viscera made by the inexpert hands of a new servant, caused fever and probably acute renal failure as illustrated by subsequent worsening of dropsy (swollen legs and testicles, abdominal fluid retention (peritonitis?).

Pius V underwent while he was apostolic nuncio in Germany a painful, expensive and invalidating surgery for a huge breakable bladder stone that required three months of rehabilitation and caused loss of renal function as attested by frequent nocturia polyuria. $\mathrm{He}$ refused years later to undergo a second surgery.

Autopsy revealed stones in Gregory XIV and Leo XI, indirect signs in Alexander VII. A triple stroke was the terminal cause of death of Clement IX, whereas, syncope, aphasia and heart block preceded the demise of Pius V.

The burden of calcium stone disease forced popes to abstain from their duties, even from very important ceremonies and events marking the calendar of the Holy See. For Pope Innocent XIII, absences from work were so frequent that daily life was disrupted in the Vatican state. Inability to perform papal duties was seen in 8 of 11 popes $(72.3 \%)$.

Urosepsis was the cause of death of Boniface IX, Hadrian VI, Pius V, Gregory XIV, Leo XI, Alexander VII, Clement IX, and Innocent XIII. Urine suppression was a contributory factor for deaths of the Gregory XIV, Pius V, and Innocent XIII.

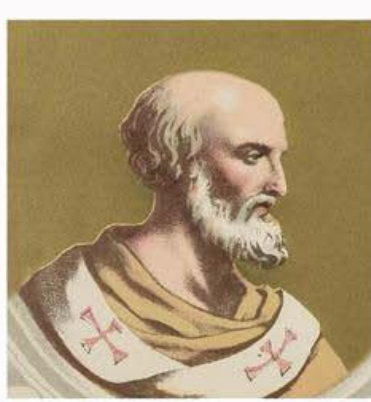

Vigilius

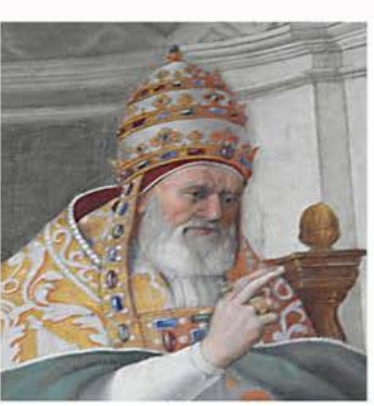

Gregory IX

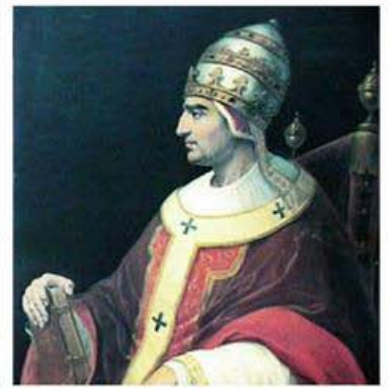

Gregory XI

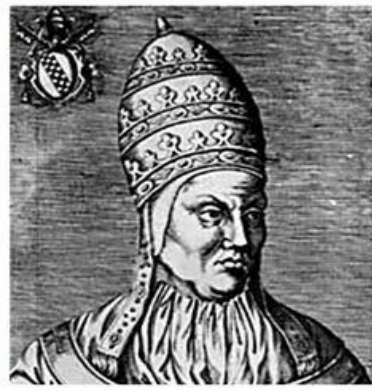

Boniface IX

Figure 1: Popes ruling in the years 537-1404 


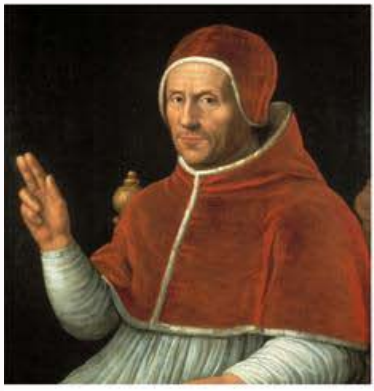

Hadrian VI

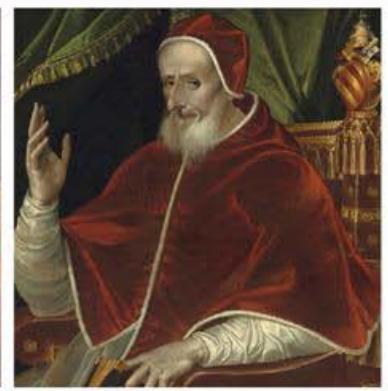

Pius V

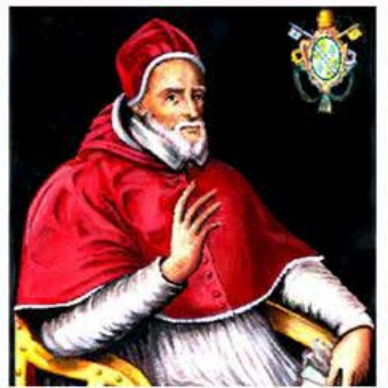

Gregory XIV

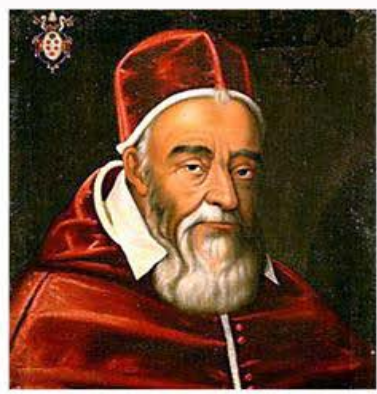

Leo XI

Figure 2: Popes ruling in the years 1522-1605.

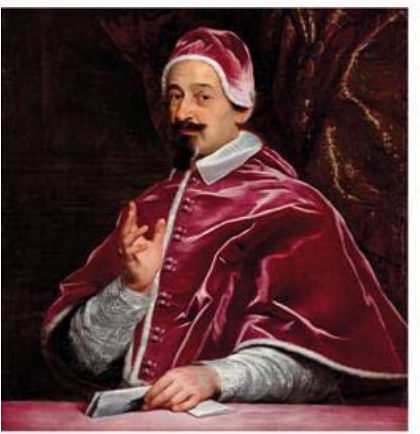

Alexander VII

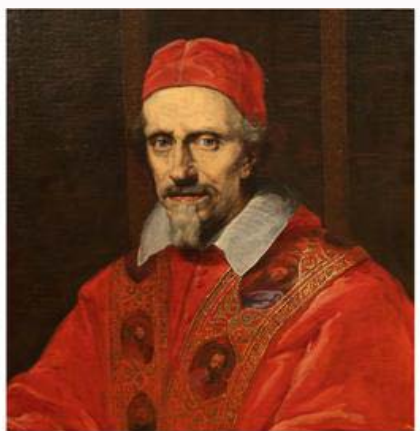

Clement IX

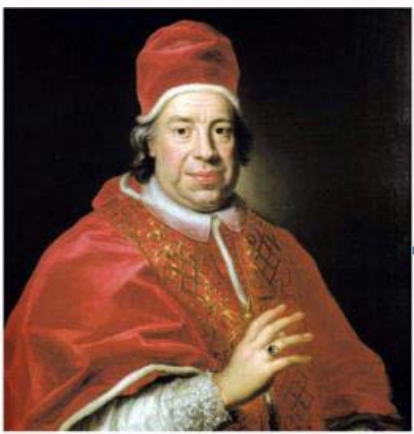

Innocent XIII

Figure 3: Popes ruling in the years 1655-1724.

Table 2: Kidney stone disease in popes with calcium and uric acid stones. Data on uric acid stoen formers are from [15].

\begin{tabular}{|l|c|c|}
\hline & Calcium Stone Formers & Uric Acid Stone Formers+ \\
\hline No. & $11 / 264(4.1 \%)$ & $25 / 264(9.47 \%)$ \\
\hline Age at death (yrs) & $61 \pm 8.9$ & $70.6 \pm 9.7 *$ \\
\hline Inability to perform & $8 / 11(72.3 \%)$ & $22 / 25(88 \%)$ \\
\hline Renal deaths & $11 / 11(100 \%)$ & $13 / 26(50 \%)$ \\
\hline With urosepsis & $8 / 11(70.3 \%)$ & $10 / 26(38.5 \%)$ \\
\hline With stroke & $2 / 11(18.2 \%)$ & $7 / 26(26.9 \%)$ \\
\hline Year of death of $1^{\text {st }}$ pope & 555 & 1724 \\
\hline Year of death of last affected pope & 604 \\
\hline
\end{tabular}

${ }^{*} \mathrm{p}<0.0001$

At death, Vigilius, Gregory XI and Boniface IX were 50 years old or less. Gregory XIV was 57, Leo XI and Clement IX were 70 years old, Gregory IX the oldest died at 71. Mean age at death was $61 \pm 8.9$ (Mean \pm SD).

Among the therapies they were prescribed we list donkey milk, manna ash, purgatives (including Epsom salts), bloodletting. Thermal treatment was prescribed to Pius V who visited Bagni dI Lucca (a spa for vips, visited also by de Montaigne), Gregory XV "bathed in the hot waters of Viterbo" and Alexander VII at thermal baths near Cologne. Innocent XIII drank the waters from Vetriolo (near Trent).

\section{Discussion}

The study shows that calcium stones affected the life of 11 of 264 popes (4.1\%) living between 34-2005 AD. The first death due to non-gouty kidney stone disease occurred in $555 \mathrm{AD}$ (Pope Vigilius), the last in $1724 \mathrm{AD}$ (Pope Innocent XIII). The disease was highly recurrent in 9 of 11 popes (81.8\%). Mean age at death was 63.1 years (interval 49-71) that is short for popes [16]. The short lifespan is in good keeping with the notion that KSD is a systemic complex disease $[52,53]$. Thus, a "stone family" of experts is needed to disclose the needs of these patients [53].

To understand the real meaning of a $4.1 \%$ prevalence, we can take into consideration that the prevalence of kidney stones is $8 \%$ to $10 \%[1,54]$ and that a $8.8 \%$ prevalence was found in persons aged 40 years or more in an Italian urban population [55]. We also know that expert assessment of stone composition indicates that $70 \%$ to $85 \%$ of calculi are made of calcium (approximately $60 \%$ to $70 \%$ from calcium oxalate and $15 \%$ from calcium phosphate). Kidney stones formed from uric acid account for $5 \%$ to $10 \%$ [56-58]. Thus, by assuming a $10 \%$ prevalence of kidney stone disease, we expected a total of 26 popes suffering from kidney stone disease (100\% of all popes), 22 as calcium stone formers ( $85 \%$ as calcium stone formers).

The number of popes with calcium renal stone disease is $50 \%$ lower than expected by the projection in the past using populationbased data. The gap might be mitigated in part, by silent stones as 


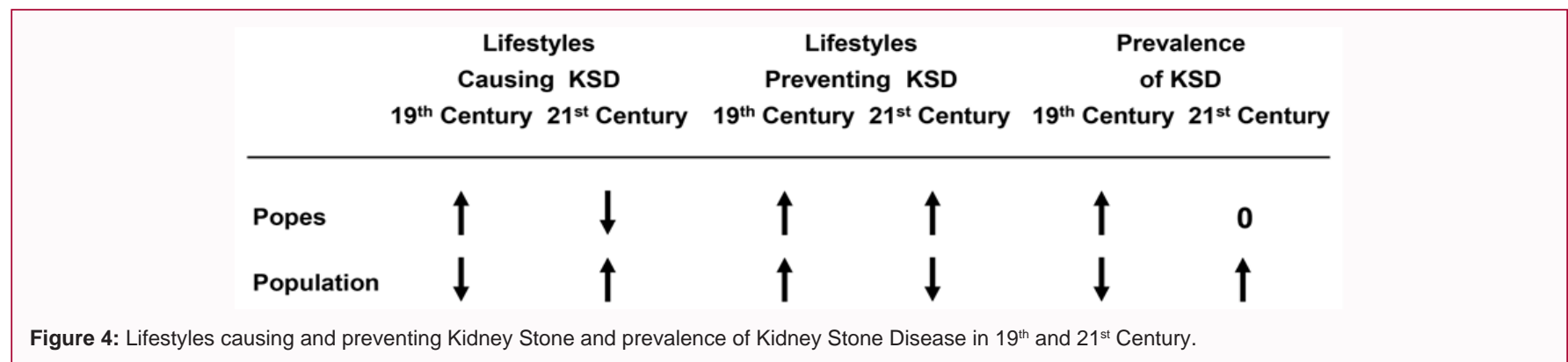

indicated by population-based studies [54] investigating potential kidney donors $[59,60]$.

Calcium stone disease was probably caused by an excessive intake of animal protein and salt. Because of the high social rank even sober and frugal popes lived in an environment where meals were plentiful in meat and salt. In the history of the papacy, one can find the descriptions of lavish banquets. For example, one can mention the party of Cardinal Pietro Riario in Honor of Princess Eleonora D'Aragona. "The party lasted no less than 6 hours. In 3 courses a total of 44 dishes were served at tables: Whole dears, goats, calves, hares, cranes, peacocks, pheasants and finally even a bear" [61].

High protein intake causes hypercalciuria due to bone reabsorption promoted by the acid load, high filtered calcium load, high intratubular sulphate concentration (i) and hyperoxaluria (ii) Salt intake $[62,63]$ (measured by urinary sodium), correlates with the prevalence of hypercalciuria independently with intestinal Calcium absorption and mainly via renal mechanisms [64]. The acidic load causes a state of subclinical metabolic acidosis [65-68].

These data likely underscore the changes in epidemiology driven by dietary habits including consumption of animal protein and sodium $[3,69,70]$.

Many studies have disclosed the benefits of a Dash-Style diet in reducing the risk of kidney stones [71-76]. A recent paper looking at population studies as well as case histories of persons affected by renal stones makes the case for such a diet in addition to other changes in lifestyle and the use of freshly prepared meals [72]. Adherence to a Mediterranean diet was also associated with a lower risk of developing kidney stones [77].

A total of 8 of 11 popes $(72.7 \%)$ died from urosepsis caused by urinary tract infection due to obstruction, mainly ureteral stones [73]. Urosepsis is a critical condition characterized by severe sepsis and shock. It is still associated with high mortality due to complex pathophysiological mechanisms that only know are recognized, but still hard to cure [78-84]. We can consider high fever, positive fluid balance, oliguria, as clinical indicators [77-81].

Calcium kidney stone disease caused a significant reduction of quality of life among popes and inability to perform duties. This was due to recurrent episodes of colic associated with pain and fever that needed time to be treated. This aspect of inability to perform duties is important in our day and age and is monitored by healthcare systems since absence from work for colic, and its treatment places an economic burden on society $[84,85]$.

In Table 2 we compare the data in popes with calcium stone with data in popes with uric acid stones [15]. The prevalence of uric acid stone formers was more than double the stone formers of non gouty origin. Popes with calcium stone disease had significantly shorter lives all of them died of kidney disease that was met only by $50 \%$ of popes with gout. In addition, urosepsis was the main cause of death in non gouty stone formers.

Stroke caused deaths of calcium stone formers and gouty popes. The association has been supported by recent findings both for uric acid stone formers [82-86] and calcium stone formers [86].

However, kidney stone diseases of calcium and uric acid origin have disappeared from the Vatican Palaces. This might be explained by the Theory of Epidemiological Transition [87].

The theory was proposed in a landmark paper by Abdel R Omran [88] after the conquest of infectious disease [89] that took place after World War II and the emergence of degenerative and "man-made diseases", after World War II. Using demographical tools, Omran analyzed the changing patterns of population age-distribution in relation to changes in mortality, fertility, life expectancy, causes of death. He identified three ages in humankind: the age of famine and pestilence (life expectancy $<30$ years), the age of "receding pandemics" (age at death 30 to 50 years), and the "age of degenerative diseases and man-made disease" (life expectancy $>50$ year). The theory has been updated frequently, and finally poverty (initially neglected) has been taken into consideration along with income and education level [9093]. This is relevant as the theory appropriately explains the differences the gap about between high prevalence of gout in popes and low but slightly increasing prevalence in the general population. The data will be discussed in terms of lifestyles, income and education. It has been shown [68] that rich and educated people lack self control as much as poor uneducated people when it comes to health issues associated with morbidity and mortality [90-93]. However, rich educated people when made aware of the risk connected to those diseases modify their lifestyles, whereas poor uneducated people may not. Thus, the latter group experience morbidity and mortality (third transition phase) at the time rich well educated people have achieved protection.

By applying the above concepts to kidney stone disease and gout (Figure 4), it may be said that popes since the beginning of the twentieth century have had a high prevalence of kidney stones disease because of lifestyle (high protein intake and high salt consumption). Those lifestyles were later corrected by education that made kidney stone disease disappear. Thus, in 2021 kidney stone disease has no place in the apostolic palaces. By contrast, poor people because of under nutrition (limited protein, high cost of salt) were not burdened by kidney stones. Nutrition, working conditions, commuting back and forth from work, avoiding obesity provided them protection from kidney stone disease. After World War II things have changed. Protein, alcoholic beverages and soft drinks are affordable to the general population. Therefore, in the USA and Italy, the prevalence of kidney stone disease is increasing and will continue to do so since 
education has failed to influence lifestyles.

The study takes into account the various treatments prescribed by personal physicians and archiaters over the centuries to cure renal stone disease. Popes, patrons of various universities and innumerable hospitals, were assisted by high rank physicians among the best of their times. They were prescribed purgatives, waters, thermal treatments, bloodletting, and surgery. We also learn that managing stones has always been a costly therapy as shown by Pius V.

This study confirms that popes are an interesting model to study diseases in the upper classes since they actively participated in the religious, social and political history of Europe and beyond. Thus, their lives have been and are continually scrutinized through the analysis of the huge volume of documents related to them as a prerequisite for history [10-15].

\section{Acknowledgements}

Joseph Sepe MD, Professor of Biological Sciences, University of Maryland Global Campus, USA, Adjunct Professor Department of Mathematics and Physics University of Campania, Luigi Vanvitelli, Naples, Italy for helping us to say what we wanted to say in English.

Figure 1-3 includes 11 popes and are all public domain: 1 . Vigilius. Oleografia Panigati e Meneghini Milano. Cromolitografia in L. Tripepi, Ritratti e biografie dei romani pontefici: da S. Pietro a Leone 13, Roma, Vaglimigli Davide, 1879. Municipal Library of Trento; 2. Gregory IX. Raphael. Detail from fresco of Pope Gregory IX approving the Decretals, 1511, Fresco Stanza della Segnatura, Palazzi Pontifici, Vatican, Vatican City State; 3. Gregory XI. Henri Auguste César Serrur (1794-1865). Palais des PapesAvignon, France; 4. Boniface IX. Author and date: unknown, 5. Hadrian VI. Jan van Storel (1495-1562). Pope Adrian VI (Hadrian VI) (1459-1523). Centraal Museum of Utrecht, 6. Pius V. Follower of Bartolomeo Passarotti (1529-1592). The original by Bartolomeo Passarotti in the Walkers Art Gallery, Baltimore; 7. Gregory XIV. Vatican city. http:// www.catholicsites.org/popes/counterreform.html; 8. Leo XI. Author and date: unknown. Contemporary $17^{\text {th }}$ century image; 9 . Alexander VII. Giovanni Battista Gaulli (1639-1709). https://wannenesgroup. com/lots/174-1450-giovan-battista-gaulli-detto-il-baciccio/Private collection; 10. Clement IX. Gianlorenzo Bernini. Opera propria; 11 Innocent XIII. Unidentified painter- $18^{\text {th }}$ century.

\section{References}

1. Gambaro G. Empirical therapy or precision medicine for kidney stone formers in the '-omics' era? Urolithiasis. 2019;47(1):1-3.

2. Lieske J, Wang $X$. Heritable traits that contribute to nephrolithiasis. Urolithiasis. 2019;47(1):5-10.

3. D'Alessandro C, Ferraro PM, Cianchi C, Barsot M, Gambaro G, Cupisti A. Which diet for calcium stone patients: A real-world approach to preventive care. Nutrients. 2019;11(5):1182.

4. Gambaro G, Ferraro MP, Capasso CB. Calcium nephrolithiasis, metabolic syndrome and the cardiovascular risk. Nephrol Dial Transplant. 2012;27:3008-10.

5. Gambaro G, Groppi E, Bushinky D, Jaeger Ph, Cupisti A, Ticinesi A, et al. The risk of chronic kidney disease associated with urolithiasis and its urological treatments: A review. J Urol. 1917;198(2):268-73.

6. Rule AD, Roger VL, Melton LJ $3^{\text {rd }}$, Bergstralh EJ, Li X, Peyser PA, et al. Kidney stones associate with increased risk for myocardial infarction. J Am Soc Nephrol. 2010;21(10):1641-4.

7. Ferraro PM, Taylor EN, Eisner BH, Gambaro G, Rimm EB, Mukamal
KJ, et al. History of kidney stones and the risk of coronary heart disease. JAMA. 2013;310(4):408-15.

8. Domingos F, Serra A. Nephrolithiasis is associated with an increased prevalence of cardiovascular disease. Nephrol Dial Transplant. 2011;26(3):864-8.

9. De Santo NG, Bisaccia C, De Santo LS. Causes of death due to disease of the genito-urinary system and of the heart among 264 popes in the years 65-2005 AD: First approach. Nephrol Dial Transplant. 2019;34(1): gfz103. SP804.

10. De Santo NG, Bisaccia C, De Santo LS. Deaths caused by cardiorenal disease among 264 popes from St. Peter to St. John Paul II. Hellenic Nephrology. 2019;31:158.

11. De Santo NG, Bisaccia C, De Santo LS. Papal deaths caused by cardiorenal disease. First approach. Arch Hell Med. 2020;37(S2):S177-S181.

12. Bisaccia C, De Santo LS, De Santo NG. Gout a papal disease: A study in 20 pontiffs (540-1830AD). Nephrol Dial Transplant. 2020;35(3):gfaa144. P1836.

13. Bisaccia C, DE Santo LS, De Santo NG. MO1029. Renal stone disease in 193 pontiffs from Vigilius to Pius VIII (537-1830). Nephrol Dial Transplant. 2021;36(s1).gfab105.001.

14. De Santo NG, Bisaccia C, De Santo LS. Gout: a papal disease-a historical review of 25 gouty popes (34-2005 AD). J Nephrol. 2021.

15. Retief FP, Cilliers L. Disease and causes of death among popes. Acta Theologica. 2005;26(2:)S233-S246.

16. Gualino L. Storia medica dei Romani pontefici. Minerva Medica, Torino,1934.

17. Ceccarelli G. La salute dei pontefici. Da Alessandro VI a Leone XIII (1492-1503). Ancora, Milano, 2001.

18. Cosmacini G. La medicina dei papi. Laterza, Roma, 2018.

19. Platina. Delle vite dei pontefici. In Venetia, appresso Domenico Farri, 1588.

20. Marini G. Degli archiatri pontifici. Stamperia Pagliarini, Roma, 1784.

21. De Novaes G. Elementi di Storia de' Sommi Pontefici. In sette volumi. Roma, 1775-92.

22. Henrion MLA. Storia Universale della Chiesa dalla predicazione degli apostoli fino al Pontificato di Gregorio XVI. 12 Volumes. Stabilimento Tip. della Minerva Sebezia, Napoli, 1842-9.

23. Von Ranke L. Storia dei Papi. Ghibli, Mlano, 2014.

24. Von Pastor L. Storia dei Papi dalla Fine del Medio Evo. XVi Vol, 200 Tomes. Desclée \& Ci. Editori Pontifici, Roma, 1958.

25. Paravicini Bagliani A. Medicina e scienze della natura alla corte dei papi del duecento. Centro Italiano di Studi sull'alto Medioevo, Spoleto, 1991.

26. Paravicini-Bagliani A. The pope's body, Chicago, University of Chicago press, 2000.

27. Maxwell-Stuart PG. Chronicle of the Popes. Thames and Hudson, London, 1997.

28. Reardon WJ. Deaths of the Popes. McFarland \& Company, Jefferson, North Carolina, 2010.

29. Encyclopaedia Britannica. online

30. I Papi da Pietro a Francesco.Treccani il portale del sapere.

31. Catholic Encyclopedia.

32. Castiglioni C. Breve storia dei papi. Edizioni Tramontana, Milano, 1959.

33. Gualino L, op. cit., p. 393.

34. De Novaes G, op.cit. Vol. III, p. 200. 
35. De Novaes G, op.cit. IV, p. 225-226.

36. Gualino L, op cit, p. 394.

37. De Novaes G, op. cit, IV, p.280.

38. Reardon. op.cit. p. 138.

39. De Novaes G, op. cit. IV, p.135.

40. De Novaes G. op.cit, VII, pp 25-260.

41. De Novaes G, op. cit. IV, 263.

42. von Pastor L. Storia papi, Vol I-XVI. Desclew \& C., Roma, X, 1910. p. $543-$ 59.

43. Marini G. Degli archiatri pontifici. Stamperia Pagliarini, Roma, 1784.

44. De Novaes G, op. cit. X, p. 190-192

45. von Pastor, op. cit. XIV, p. 322-323

46. De Novaes G, op. cit. X, p. 127-128.

47. von Pastor L, op. cit. XIV, p. 394.

48. von Pastor L, op. cit., XIV, p. 625.

49. Gualino L, op. cit. p. 199-200.

50. von Pastor L, op. cit. XIV, p. 384-385.

51. Baggio B, Gambaro G. Calcium nephrolithiasis: A systemic disease. It J Miner Electrol Metab. 1996;10:47-8.

52. Gambaro G, Trinchieri A. Recent advances in managing and understanding nephrolithiasis/nephrocalcinosis. F1000 2016;5:F1000 Faculty Rev-695.

53. Ramello A, Vitale C, Marangella M. Epidemiology of nephrolithiasis. J Nephrol. 2000;13 Suppl 3:S45-50.

54. Croppi E, Ferraro PM, Taddei L, Gambaro G. Gea Firenze Study Group Prevalence of renal stones in an Italian urban population: A general practice-based study. Urol Res. 2012;40(5):517-22.

55. Lieske JC, Rule AD, Krambeck AE, Williams JC, Bergstralh EJ, Mehta RA, et al. Stone Composition as a Function of Age and Sex. Clin J Am Soc Nephrol. 2014;9(12):2141-6.

56. Delbarba E, Terlizzi V, Dallera N, Izzi C, Scolari F Delbarba E, et al Hyperuricemia and gout. G Ital Nefrol. 2016;33(S68):gin/33.S68.16.

57. López M, Hoppe B. History, epidemiology and regional diversities of urolithiasis. Pediatr Nephrol. 2010;25(1):49-59.

58. Kim IK, Tan JC, Lapasia J, Elihu A, Busque S, Melcher M. Incidental kidney stones: A single center experience with kidney donor selection. Clin Transplant. 2012;26(4):558-63.

59. Lorenz EC, Lieske JC, Vrtiska TJ, Krambeck AE, Li X, Bergstralh EJ, et al. Clinical characteristics of potential kidney donors with asymptomatic kidney stones. Nephrol Dial transplant. 2011;26(8):2695-700.

60. Von Pastor L., op.cit II: p. 463-4.

61. Giannini S, Nobile M, Sartori L. Acute effects of moderate dietary protein restriction in patients with idiopathic hypercalciuria and calcium nephrolithiasis. Am J Clin Nutr. 1999;69:267-71.

62. Breslau NA, Brinkley L, Hill KD, Pak CYC. Relationship of animal protein-rich diet to kidney stone formation and calcium metabolism. J Clin Endocrinol Metab. 1988;66(1):140-46.

63. Cirillo M, Ciacci C, Laurénzi M, Mellone M, Mazzacca G, De Santo NG Salt intake, urinary sodium, and hypercalciuria. Miner Electrolyte Metab. 1997;23(3-6):265-8.

64. Taylor EN, Stampfer MJ, Curhan GC. Dietary factors and the risk of incident kidney stones in men: New insights after 14 years of follow-up. J Am Soc Nephrol. 2004;15(12):3225-32.
65. Trinchieri A, Maletta A, Lizzano R, Marchesotti F. Potential renal acid load and the risk of renal stone formation in a case-control study. Eur J Clin Nutr. 2013;67(10):1077-80.

66. Trinchieri A, Lizzano R, Marchesotti F, Zanetti G. Effect of potential renal acid load of foods on urinary citrate excretion in calcium renal stone formers. Urol Res. 2006;34(1):1-7.

67. Trinchieri A, Zanetti G, Currò A, Lizzano R. Effect of potential renal acid load of foods on calcium metabolism of renal calcium stone formers. Eur Urol. 2001;39(Suppl 2):33-6; discussion 36-7.

68. López M, Hoppe B. History, epidemiology and regional diversities of urolithiasis. Pediatr Nephrol. 2010;25(1):49-59.

69. Heilberg IP. Update on dietary recommendations and medical treatment of renal stone disease. Nephrol Dial Transplant. 2000;15(1):117:120.

70. Holmes RP, Goodman HO, Hart LJ, Assimos DJ. Relationship of protein intake to urinary oxalate and glycolate excretion. Kidney Int. 1993;44:36672

71. Borghi L, Schianchi T, Meschi T, Guerra A, Allegri F, Maggiore U, et al. Comparison of two diets for the prevention of recurrent stones in idiopathic hypercalciuria. N Engl J Med. 2002;346(2):77-84.

72. Taylor EN, Fung TT, Curhan GC. DASH-style diet associates with reduced risk for kidney stones. J Am Soc Nephrol. 2009;20(10):2253-9.

73. Ferraro PM, Taylor EN, Gambaro G, Curhan GC. Dietary and lifestyle risk factors associated with incident kidney stones in men and women. J Urol. 2017;198(4):858-63.

74. Prezioso D, Strazzullo P, Lotti T, Bianchi G, Borghi L, Caione P, et al. Dietary treatment of urinary risk factors for renal stone formation. A review of CLU Working Group. Arch Ital Urol Androl. 2015;87(2):105-20.

75. Rodriguez A, Curhan GC, Gambaro G, Taylor EN, Ferraro PM. Mediterranean diet adherence and risk of incident kidney stones. Am J Clin Nutr. 2020;111(5):1100-6.

76. Wagenlehner FME, Lichtenstern C, Rolfes C, mayer K, Uhle K, Weidner W, et al. Diagnosis and management of urosepsis. Int J Urol. 2013;20(10):96370 .

77. Levy MM, Artigas A, Phillips GS, Rhodes A, Beale R, Osborn T, et al. Outcomes of the surviving sepsis campaign in intensive care units in the USA and Europe: A prospective cohort study. Lancet Infect Dis. 2012;12(12):919-24.

78. Bone RC, Balk RA, Cerra FB, Dellinger RP, Fein AM, Knaus WA, et al. Definitions for sepsis and organ failure and guidelines for the use of innovative therapies in sepsis. The ACCP/SCCM Consensus Conference Committee. American College of Chest Physicians/Society of Critical Care Medicine. Chest. 1992;101(6):1644-55.

79. Levy MM, Fink MP, Marshall JC, Abraham E, Angus D, Cook D, et al. 2001 SCCM/ESICM/ACCP/ATS/SIS International Sepsis Definitions Conference. Crit Care Med. 2003;31(4):1250-6.

80. Dellinger RP, Levy MM, Rhodes A, Annane D, Gerlach H, Opal SM, et al. Surviving sepsis campaign: International guidelines for management of severe sepsis and septic shock: 2012. Crit Care Med. 2013;41(2):580-637.

81. Saigal CS, Joyce G, Timilsina AR. Urologic Diseases in America Project. Direct and indirect costs of nephrolithiasis in an employed population: opportunity for disease management? Kidney Int. 2005;68(4):1808-14.

82. Raja A, Wood F, Joshi HB. The impact of urinary stone disease and their treatment on patients' quality of life: a qualitative study. Urolithiasis. 2020;48;227-34.

83. Kim SY, Guevara JP, Kim KMI, Choi HK, Heitjan DF, Albert DA. Hyperuricemia and risk of stroke: A systematic review and meta-analysis. Arthritis Rheum. 2009;61(7):885-92.

84. Sing JA, Ramachandaran R, Yu S, Yang S, Xie F, Yun H, et al. Is gout a risk 
equivalent to diabetes for stroke and myocardial infarction? A retrospective claims database study. Arthritis Res Ther. 2017;19(1):228.

85. Lin SY, Lin CL, Chang YJ, Hsu WH, Lin CC, Wang IK, et al. Association between kidney stones and risk of stroke. A nationwide population-based cohort study. Medicine (Baltimore). 2016;95(8):e2847.

86. Mc Keown R. The epidemiologic transition: Changing patterns of mortality and population dynamics. Am J Lyfestyle Med. 2009;3(1 Suppl):19S-26S.

87. Omran AR. The epidemiologic transition. A theory of the epidemiology of population change. 1971. Milbank Q. 2005;83(4):731-57.

88. Caldwell JC. Population health in transition Bull. World Health Org 2001;71(1):159-60

89. Pearson TA. Education and income: Double edged swords in the epidemiologic transition of cardiovascular disease. Ethn Dis. 2003;13(Suppl 2):S158-63.
90. KcKeown RE. The epidemiologic transition: Changing patterns and mortality and population dynamics. Am J Lyfestile Med. 2009;3(1Suppl):19S-26S

91. Pearson TA. Socioeconomic status and cardiovascular disease in rural population. In: Stamler J, Hazuda H, editors. Report on the conference on Socioeconomic Status and cardiovascular disease. Washingtoon DC: National Heart, Lung, and Blood Institute; 1995:101-108

92. Marmot MG, Stanfieklld S, Patel C, North F, Head J, White I. Health inequalities among British civil servants. Lancet. 1991;337(8754):1387-93.

93. Kaplan G, Keil J. Socioeconomic factors and cardiovascular disease: A review of the literature. Circulation. 1993;88(4 Pt 1):1973-88. 